\title{
Phil Harris
}

The Business School, Manchester Metropolitan University

\section{To Spin or not to Spin that is the Question: The \\ Emergence of Modern Political Marketing}

In November The US elections were thrown into chaos by the humble chad, a paper perforation on a punch operated ballot paper. The election campaign had cost a total of $\$ 3$ billion (Washington Post, $6^{\text {th }}$ November) the largest ever. Eventually George W, Bush emerged as the victor after various court rulings. He had been elected however more as a result of the effective use of marketing than confusion in the ballot. He won because of his campaigns ruthless targeting of swing voters and marginal states.

In June 2001, Tony Blair was re-elected Prime Minister as a result of the Labour party's second landslide victory in the UK General Election. The result was no fluke but had been based on a long-term strategic political marketing planning process, which had been plotted and refined by the marketing headquarters at Millbank.

All this of course will be denied or under played by politicians because there are no votes in it, but the reality is that the use of marketing in politics is greater than at any time before and is a major service business and operation. This article outlines political marketing's evolution, relationship to other communications, implications for the voter and society and how it can be applied to bring victory and thus power.

Keywords: political marketing, polling, voters, lobbying, elections, communications, citizenship, public affairs, politics, politicians

Introduction

\section{Introduction}

\section{The United States of America}

The concept of political marketing originated in the United States (Cutlip 1994, Kavanagh 1995). Some writers see its beginnings in the 1950s and 1960s (Maarek 1995, Beresford 1998) or at the beginning of the century (McNair 1996). It has been argued that political marketing became inevitable because of the mass electorate and well developed mass media (Harrop 1990). According to Mareek (1995), the main factors responsible for the early development of the phenomenon in the US are the presidential system, tradition of election for all public offices and rapid expansion of modern mass media. The US also provides a good example of the early usage of typical marketing tools such as direct mail, political advertising and publicity stunts in

ISSN1469-347X/2000/010001+14 £8.00/0 OWestburn Publishers Ltd.


political communication (Perry 1968, Rothschild 1978, Melder 1992, Newman 1994 and 1999). Elements of political marketing can be seen in not for profit markets (Kotler and Andreason, 1991) and of course lobbying within Public Affairs (Griffin, Fleisher, Brenner and Boddewyn 2001).

\section{Great Britain}

In Britain, political marketing as a phenomenon fully developed in the 1980s under the party leaderships of Thatcher and Kinnock who aimed to integrate all political communications and control the news agenda, however it has also been suggested that major political parties have been engaged in marketing related activities for most of the twentieth century (Harrop 1990, Smith and Saunders, 1990, Kavanagh 1995, Wring 1996 and Harris and Wring 2002).

It has been argued that there is a great increase in focus on packaging and presentation of leaders, partly due to the move of the Labour Party towards the centre ground ( Foley 1993, Jones 1995, Norris 1996). Like in the USA, television has the most significant impact on political communication and the factor which dominates all other considerations by party strategists is the battle to dominate the television agenda (Butler and Kavanagh 1992, Crewe and Gosschalk 1995, Scammell 1995, Harris and Wring, 2002). These developments in campaign communications resulted in the dramatic increase in the potential influence of the media (Norris 1997b).

\section{THE POLITICAL MARKETING MIX}

In order to obtain clarity and order in the presentation of the various tools used in political marketing and to illustrate analogies with mainstream marketing, classic division of marketing mix into promotion, product, price and place (Kotler 1975) has been adopted.

\section{PROMOTION}

Promotion plays the crucial role in political marketing mix. It comprises various elements and techniques such as advertising, public relations, direct mail, and pseudo-events planned to gain publicity and attention. Four influential areas of innovation in technology, computers, television and direct mail have directly affected the way the campaigns are run (Newman 1994 and 1999). Some of the applications of technological advances include database marketing, fund-raising and polling and enable the candidates to go directly to the voter. Moreover, political marketers are provided with new opportunities because of computer video and Internet development, e.g. with the possibilities of new types of advertising or direct mailing (Dean and Croft 1997) and also with new challenges connected with the development of digital television and reaching target voters.

\section{Advertising}

Televised advertising has become important because it reaches the voters 
and at the same time the party or candidates fully controls the message (Kaid and Holtz-Bacha 1995). Contrary to popular belief that political ads are solely concerned with image (Baines, Harris and Lewis, 2002), it has been found that most of political advertising is concentrated on issues or contains issue based information.. Although there are contradictory theories on the effects of political advertising, most researchers agree that it acts mostly to reinforce the existing image (e.g. Kaid and Holtz-Bacha 1995, Scammell 1995, Kavanagh 1995).

\section{Debates and Pseudo-Events}

Televised debates are increasingly regarded as the capstone of the election campaign (Maarek 1995), even though there is no evidence that they can dramatically change the outcome of the campaign (Newman 1994). Although criticised from the stand that they are mostly based on projecting the right image and not discussing policy differences (Nimmo 1970), debates, like other pseudo-events, are meant to look spontaneous but in fact are carefully staged and continue to attract the attention of the media and gain publicity for the political players.

\section{Direct mail}

Several authors stress the growing role of direct mail in the contemporary political marketing mix, e.g. Newman 1994, Maarek 1995. It is used to pretest the market, personalise and concentrate the message, raise funds, promote issues and candidates and recruit volunteers. Harrop (1990) argues that the real potential of direct mail is that it offers the opportunity to personalise one's basic message so as to convince voters that a party which can campaign so efficiently might actually be up to the job of running the country.

\section{Free media}

Wring (1997) notes the diminishing role of advertising in favour of free media publicity which is most frequently connected with public relations designed to attract favourable media attention. Greater importance of free media publicity is also acknowledged by both voting public and media strategists. News management is perhaps the most visible area of contrast between mainstream and political marketing. In political communications staff are deluged on a daily basis by journalists and need to answer highly sensitive questions; but free media strategies are not only concerned with defensive news management activities. (Franklin 1994)

\section{Negative Campaigning}

Political marketing tends to prescribe negative campaigning, especially in advertising where it is easier to attack than to propound (Kavanagh 1995, Maarek 1995, Scammell 1995). It might be the consequence of candidate focus in elections and campaigns (Popkin 1991). Although labelled by some "negative abuse" (Brendan 1992: 100), negative campaigning is not 
necessarily harmful to political discourse and, in fact, essential for genuine debate (Jamieson 1992). It ensures that policy and politician's reputations are examined. Media accepting the role of opposition expose the flaws and guarantee transparency of political processes (McNair 1996).

Place

Wring (1997) points out that a network at grassroot level is at the heart of a placement strategy. Local electioneering takes the form of traditional activities such as canvassing and leafleting and "getting the vote out" on the polling day (Kavanagh 1970, Denver and Hands 1992). In the marketing era of modern campaigns it is more important to identify and contact potential supporters than to persuade them (Wring 1997).

Price

Although some scholars discount the pricing element of political marketing mix, e.g. Farrell (1996), others, e.g. Niffenegger (1990) Wring (1997), justify the relevance of price as its constituents comprise voter's feelings of national, economic and psychological hope or insecurity. Discussing the price aspect of voting behaviour, Wring points out two aspects, one resulting from negative campaigning which are designed to build voters' fear, and the other resulting from the voter's "feelgood factor". Also Reid (1988) sees votes as a psychological purchase and draws parallels between voting and buying.

\section{Product}

The main differences in views what constitutes a political product, e.g. Harrop (1990), Newman (1994), Scammell (1995), have already been presented. Wring (1997) points out three key aspects of the political marketing product: party image, image of leader and policy commitments (manifesto). Different groups of voters are susceptible to the appeals of these key elements in varying degrees (Worcester 1987, 1991). There is an agreement, however that the common feature of media election coverage is an increase in using appeals based on promotion of image at the expense of issues (Biocca 1991, Franklin 1994). Moreover, there is also growing emphasis of the importance of leader image, e.g. Foley (1993), Crewe and King (1994), which is the reason for the personalisation of politics as described by Swanson and Mancini (1996).

\section{Focus on Election Campaigns}

Pointing out the infancy of the conceptual development of political marketing, Lock and Harris (1996), draw attention to the fact that much of theoretical work to date has been focused on the immediate periods before elections. Also the models of political marketing e.g. Wring (1997), Maarek (1995), (Newman 1994) are based on the period of the election campaign. In the era of campaigning though, described by some as the permanent campaign (Norris 1997a, 1997b), there is no clear difference between the period 
directly before the election and the rest of the political calendar.

\section{Political Marketing and Propaganda}

Political marketing is often mistaken with propaganda (O'Shaughnessy 1990, Scammell 1995). There is agreement about difficulty in defining the term propaganda (O'Shaughnessy 1996). Jowett and O'Donnell (1992) stress the elements of manipulation and deliberate intent to influence. They see propaganda as "the deliberate and systematic attempt to shape perceptions, manipulate cognitions and direct behaviour to achieve a response that furthers the desired intent of the propagandist". Other definitions (Pritkanis and Aronson 1992, Salmon 1989) also point out its manipulative and negative aspects, and explicit bias as commonly attributed feature as well as simplification, hyperbole and ideology (O'Shaughnessy 1996). Pritkanis and Aronson state that the term started to be widely used at the beginning of the twentieth century when it was employed to describe the persuasion methods used during the First World War and later to describe tactics of totalitarian regimes.

Although there are similarities between the political marketing and propaganda such as the fact that both give little information to the receiver, use of special propagandists, and use of controlled media (O'Shaughnessy 1990), the difference lies in the element of reciprocity present in the political marketing process (Scammell 1995). From the political marketing point of view product may be changed according to voters' wants, while propaganda begins from the premise that public opinion can be won over to the propagandist's cause (O'Shaughnessy 1990, Scammell 1995). The marketing approach, adopted by political marketing, is sensitive to the needs of the customer which is alien to the idea of propaganda. In contrast, propaganda is didactic (O'Shaughnessy 1996).

\section{Public Relations and Political Marketing}

As political marketing is an interdisciplinary subject, the boundaries between political marketing and public relations are not clear (Harris and Moss, 1999 and 2001). For most political marketers the areas of immediate interest are media relations where public relations techniques are applied, communication processes between candidates and publics and building of the image and reputation which is one of the core concepts of public relations.

Political marketing scholars, however, mostly ignore the theoretical foundations of public relations. In the majority of theoretical political marketing literature, public relations is referred to as merely a publicity function or media relations (e.g. Sabato 1981, Maarek 1995). Some researchers see public relations as a vital component in the political marketing mix, concerned with image and persuasion (Scammell 1995) or

refer to reactive public relations which is concerned with the management of 
damage limitation (Egan 1999),

Public Relations and Politics

McNair (1996) argues that the rise of political public relations is the inevitable consequence of the process in which mass media has become the centre of opinion formulation and decision making. Political public relations has proactive and reactive dimensions. It seeks to initiate changes in such variables as public opinion, voting behaviour and journalistic agendas. It also reacts to events with potential negative consequences, limiting the potential damage.

The use of public relations in politics has been criticised from the point of view that it undermined the rationality of political discourse (Habermas 1984, Hart 1987 and McNair 1996). Others (e.g. Garnham 1986) similarly see public relations as manipulation and notice that the style of political performance shaped by public relations began to have more importance than the substance of policy.

There is also a confusion about the differences between political propaganda and public relations. As the term propaganda emerged to describe the rising activities such as advertising, publicity, staged events, leaked information, and took on negative connotations connected with totalitarian regimes, then the term public relations emerged to describe the concerted efforts of these opinion moulding activities with the added dimension of building mutually beneficial relationships as the goal. The nature of communication activity is, however, very different: public relations is, at least at its best, two-way communication, designed to build mutually beneficial relationships for the parts involved (Cutlip (1985).

\section{Political Marketing, Lobbying and Government: Future Research}

Although the debate on the definition and nature of political lobbying continues (Grant 1987, Harris and Lock 1996b, Harris and Moss 1999, growing literature, on pressure groups, interest groups and policy networks (Grant 1995, Richardson 1993, Smith 1993, Harris and Moss, 2001) offers useful insights and suggests tools to be used in political marketing (Harris and Lock 1996b). Harris, Gardner and Vetter (1999), Harris (2001) and Harris and Moss 2001 find a direct linkage between political marketing and interest lobbying, namely the need of political parties to raise funds to ensure their existence in the electoral market place. They claim that the need to run expensive modern political marketing campaigns forces political parties to develop close links with business. However, this area is still largely under researched for many obvious reasons.

There is also a lack of research in the area of regulation and deregulation closely connected with the border between lobbying and political marketing (Richardson 1993, Harris and Lock 1996,1996b). The latter argue that governments cannot be treated as a neutral component in the exchange perspective on political marketing. Government politicians play important 
roles in the process of exchange and governmental control is a key objective in political processes". Therefore the regulation of political marketing plays a more important role in this type of exchange than in mainstream marketing settings. These issues gain significance especially in the context of governmental regulatory involvement in competitive business arenas and especially in such areas as the deregulation of markets (Harris and Lock 1996b).

\section{Limitations of Political Marketing}

Researchers agree that it is difficult to establish how effective political marketing is (e.g. Kavanagh 1995, Scammell 1995). It is difficult to differentiate the influence that political marketing has on voters from many other general and specific factors which influence elctors in any election. Nor is there a satisfactory way to isolate and measure the effectiveness of communications campaigns. Moreover, political marketing literature tends to be specific to single countries, often to particular party cases which makes it very difficult to generalise and prescribe the right mode of action (Butler and Collins 1994).

It also has been voiced that political marketing cannot make a political party electorally successful if it has a poor strategy (Harrop 1990). Strong strategy is vital to convince the electorate that it is able to deliver quality. It has, however, potential impact to affect those who decided by reinforcing what they believe (Kavanagh 1995, Hayes and McAllister 1996, Jones 1995).

\section{Criticism of Political Marketing}

Political marketing has been criticised from the ethical stand as undermining democracy because of its ability to promote people with media abilities and right appearances, and to manipulate and mislead the voter (e.g. Sabato 1981, Newman 1994, Scammell 1995). O'Shaughnessy (1990) argues that the rise of political marketing contributes to the misperception of political processes and the ease with which solutions can be traded and implemented. Egan (1999) suggests that politicians themselves have been uneasy with the concept of marketing, complaining that it damages the political process as it concentrates on image instead of issues.

There is also a debate about ethics in conducting political campaigns. Some draw attention to the need to introduce some form of financial regulation, while others point out impracticality and difficulties in enforcing ethical standards in campaigns. Lock and Harris (1996) note widespread concerns about ethics, however they perceive much of the criticism of political marketing as nostalgia for the "good old days" which are more myth than reality.

\section{Americanisation and Modernisation}

The evolution of electoral practices in different parts of the world show convergence in spite of great differences in the political cultures, histories and political institutions of the countries concerned (Mancini and Swanson 
1996). Since many developments in modern political campaigns first became evident in the US, the process of change in the relationship between political parties, media and voters has been termed Americanisation (Mancini and Swanson 1996, Kavanagh 1995, Kaid and Holtz-Bacha 1995, Cutlip 1994, Scammell 1995). Mancini and Swanson have also suggested that campaigns become more and more Americanised as candidates, parties and media take their cues from the counterparts in the USA. Similarly, Butler and Ranney (1992) identify a range of practices such as the usie of computers, fax and direct mailing which originated in the USA but which are currently widely used outside it.

Although, as noted above, researchers subscribe to the idea of Americanisation with its key attributes such as personalisation of politics, expanding reliance on experts and advisors, growing detachment of political parties from citizens and medialisation of political life, they also point out that differences between countries exist. The main differences refer to the fact that the processes of Americanisation do not always establish themselves in identical ways or with the same consequences (Swanson and Mancini 1996), that there are differences in political structures and processes, political culture and in media systems (Kaid and Holtz-Bacha 1995) or to the fact that although things may have the same name they do not necessarily operate in the same ways e.g. American type of political party can be a loose coalition of local parties and factions which meet to win the election campaign (Tunstall 1977, Negrine 1996).

Some authors suggest that the notion of Americanisation as it refers to the export and local adaptation of campaign techniques does not reflect the complexity of the process of change in modern election campaigns. Following the theoretical hypotheses of Giddens 1990, Murdock 1993 and Tomlinson 1993, Swanson and Mancini 1996 subscribe to the process of modernisation which they consider as a more general and fundamental process of change which leads to adoption of Americanised campaign methods in different national contexts.

The process of modernisation is the consequence of increasing social complexity, (Swanson and Mancini 1996).

\section{Elements of Modern Campaigning}

\section{Personalisation of Politics}

The effect of modernisation is to empower individual political figures which produces a personalisation of politics so the voter's choice depends increasingly on his/her relationship with the individual candidate (Harris, Lock and Rees, 2000). This relationship replaces ideological bonds with a political party. Personalisation of politics results in the candidate or party's efforts to project the right image (Swanson and Mancini 1996).

Image

Contrary to the traditional schools of thought on the roots of electoral 
choice which connect choice with policy preferences or broad ideologies (e.g. Himmelweit et al's consumer model (1985), Downs' spatial model (1957) and Heath, Jowell and Curtice's (1985) account of ideological voting), political marketing literature stresses the importance of the candidate's image and its role in influencing the voter (Harrop 1990, Newman 1994, Cutlip 1994, Kaid and Holtz-Bacha 1995).

Political scientists generally agree that although under the right circumstances both images and issues can influence election outcomes, candidate's image is generally more important than issues (e.g. Bartels 1987, Carmines and Stimson 1980). Voters use their image of the candidate as a substitute for information about his performance in politics (Popkin 1991). Image formation is a difficult process as it is reconstructed in the subjective mind of an individual recipient (Nimmo 1974, Newman 1994, Maarek 1995, Wring 1997) and the fact that more significance is attached to party or candidate's image than to the policies may not be admitted explicitly (Harrop 1990).

Likewise, Scammell (1995) argues that image rather than substance is central in political marketing. She identifies the key elements candidate's image such as reputation, trustworthiness (used extensively by Bush in 2000 and Charles Kennedy in 2001) and credibility which are more important than minor ones, appearance, body language or dress. Although Scammell (1996), acknowledges the role of issues in election campaigning, she sees their importance not in their intrinsic merit but in their ability to affect the overall image of credibility and competence.

Newman (1994) sees establishing the image as a crucial element of his political marketing model. The candidate's image becomes the strategic focus of his marketing strategy. Image, next to the campaign platform, is one of the two strategic devices that are used to position the candidate. He stresses the need to design the unique image that is broad enough to relate to all possible segments of voters the candidate is trying to address, and at the same time crafted in response to his' opponents images.

Maarek (1995) sees a distinction between an image-making campaign when the candidate stands no real chance of winning and a victory campaign where the aim is to win the election and acknowledges the significance of the former. Maarek's framework for image making draws on commercial marketing's unique selling proposition formula which looks to highlight the difference between other candidates and simplification of the image and message. Similarly to Newman (1994), Maarek draws attention to the importance of consistency and difficulties to stay within the boundaries of the image.

Image is also important in advertising. Image advertising is powerful and voters remember these more then the issue advertisements (Sabato 1981). The reason is that image is something that can be instantly communicated (O'Shaughnessy 1990).

There is, however, some criticism about the role attributed to the role of image. In the view of some authors (e.g. Sabato 1981) the emphasis on 
image, at best trivialises political debate and, at worst, may mislead and deceive.

Role of Public Relations in Image Creation

A number of scholars (e. g. Grunig, J. 1992a, Grunig, J. 1992b, Grunig, L. 1993, Haberman and Dolphin 1988, Marken 1990, Pincus et al 1991) illustrate the role of public relations in exploring, defining and communicating image. As top management helps create and relate the image of the organisation to its internal and external audience in the business world in the same way political leaders and candidates in elections convey their own and their organisations' image to voters. The role of public relations is coordination, linking the efforts of marketing, finance and personnel (Moore 1960, Marken 1990). The value of public relations lies in saving money for the organisation and the effects of its application should be expected to become apparent in the long term.

Several political marketing authors acknowledges this role of public relations in image building and coordination of electoral campaigns. Kessel (1980) attributes a crucial role to public relations role in building the trustworthiness of the candidate. Kelly (1956), Newman (1994 and 1999) and Maarek (1995) point out the co-ordinationg role of public relations in media management.

\section{Scientificisation of Politics}

Drawing on the work of Habermas (1978), Swanson and Mancini (1996) point out the more frequent use of technical and scientific expertise in politics. The goal of the scientificisation process is electoral victory, not finding useful policy alternatives. Intra-party competition and focus on individuals make candidates assemble their own teams of experts (Agranoff 1972, Sabato 1981).

\section{Political Consultants}

Professionalisation of political news management gave rise to the profession of political consultants advising candidates on strategies (Kavanagh 1995, Scammell 1995). Negrine (1996) argues that it is the use of communication consultants that marks off modern electoral contests from more traditional ones. Jamieson (1992), Nimmo (1970) and Sabato (1981) note the change in the role of consultants which evolved from that of technical adviser to key communication strategy former. Several authors note growing specialisation e.g. in direct mail, media, polling (e.g. Melder 1992, Kessel 1980) and adjustments of the profession in response to the growing needs of the market, daily papers, tabloid, TV shows (Scammell 1995, Newman 1994)

There is a dispute whether political consultants positively contribute to the quality of campaigning. On the one hand political consultants work to improve communication between candidates and voters (e.g. Harrop 1990, O'Shaughnessy 1990, Newman 1994). De Vries (1989) sees polling as a 
means to more specific targeting and enhancement of two-way communication. On the other hand, there is criticism that political consultants contribute to trivialisation of politics (De Vries 1989, Sabato 1981, O'Shaughnessy 1990, Peele 1982). Political consultants are accused of encouraging candidates' worst instincts to satisfy public opinion (Sabato 1981) or called mercenaries who screen potential candidates to choose a "marketable" one (Nimmo 1970).

\section{Democratic Deficit: The Detachment of Parties from Citizens}

Increasing fragmentation of modern societies makes it harder for political leaders to know the concerns of the electorate. At the same time a decline in the membership in political parties and loss of long-standing supporters and activists has led to the loss of traditional point of contact with the electorate. Being in touch with the needs, moods and interests of citizens is especially important as parties move from ideological bases to opinion bases (Swanson and Mancini 1996). The modern substitute for interpersonal contact is the opinion poll (Herbst 1993).

\section{Polling}

Polling has come a long way since it was first used in 1820s (Sabato 1981). At present, alongside focus groups, polls, including benchmark surveys and tracking polls, are one of the most influential tools used in modern political campaigns (Newman 1994). Although opinion polls may not be reliable because of unrepresentative samples or swings in electoral mood (Butler and Kavanagh 1992, 1997) they play a major role in setting the media's campaign agenda (Newman 1994). There is concern about the impact of polls on the bandwagon effect (Newman 1994, Maarek 1995, Owen 1991).

\section{Autonomous Structures of Communication}

The role of mass media in modern campaigns has changed form being a channel of communication to an autonomous power centre in competition with other power centres (Blumler 1990, Butler and Ranney 1992, Swanson and Mancini 1996). At present, media is one of the main actors on political scene, with power to select persons and issues to be covered and to shape the public image of political leaders (Butler and Ranney 1992). The consequence for modern politics include tailoring campaigning to the needs and interests of mass media (Garnham 1992) and advancing their own agenda in covering the campaign (Semetko et al 1991) which leads to what has been described as "media-centred democracy" (Swanson 1993).

\section{Media Effects}

Several models of media effects, such as the propaganda model, minimal effects model, two-step flow model, diffusion model and consumer model, try to explain the influence of media upon the public (Kraus and Davis 1976, Weaver 1980, Blumler, 1990 and McQuail 1994). At present it is accepted 
that the mass media has little direct effect on political behaviour and acts rather as a reinforcer of opinion, however, it is also suggested that media plays an important role in shaping long term perceptions of politics and issues of importance (Kraus and Davis 1976, Kavanagh 1995).

McQuail (1976) suggests that it is the way in which media chooses to report events which may be important, as well as the omission in reporting of other events. It is also stated that the period preceding an election campaign may be more significant in shaping political opinion (Negrine 1989, Kavanagh 1995, Swanson and Mancini 1996). Swanson and Mancini suggest that that it is connected with the agenda setting role of the media because voters tend to think that issues which are given the most coverage and attention are the most important. They state that politicians try to be active in setting the agenda because they may be at an advantage if issues that appear in the news are more important to voters. Semetko et al (1994) points out that coverage may enhance or diminish a party's campaign by making one party more visible than the other.

\section{Setting the Agenda}

Agenda setting, as first described by McCombs and Shaw (1972), refers to correlation between issues given coverage by media and these seen as important by the public. It has been noted that agenda setting by media influences voters without strong views (Curran and Seaton 1991). There are links between themes in news reporting and what is recalled, understood and believed by the public (Eldridge et al 1997).

\section{Television}

There is agreement that the most important issue is to dominate the television agenda (e.g. O'Shaughnessy 1990, Swanson 1993 Newman 1994, Kavanagh 1995, Scammell 1995). Television plays a major role in accentuating the process of personalisation (Swanson and Mancini 1996). Television is the medium through which voters encounter political candidates and through television the attachments are formed that connect citizens to the representatives. Skilful use of TV is essential to cultivate personal support. Wring (1997) draws attention to the importance of unpaid media and O'Shaughnessy claims that television is the primary political marketing source (1990: 46).

\section{Shift from Citizenship to Spectatorship:}

Swanson and Mancini (1996) argue that modernisation causes changes from direct involvement in election campaigns to spectatorship. Campaigns are conducted primarily through mass media and citizens participate in them as a media audience. Because of the growth in number of groups competing for power, e.g. pressure groups, parties, media, "political spectacle" as described by Edelman (1988) it does not concentrate on solving real problems, but on respecting the symbolic commitments and showing 
To Spin or not to Spin that is the Question:

competing desires and ambitions of parties interested in the programmes. The fact that modern citizens delegate representing their interests to intermediary structures makes it easier for voters to relate to media-centred campaigns more as spectacle than political action (Swanson and Mancini).

\section{Table 1. Political Campaign Evolution}

\begin{tabular}{|c|c|c|c|}
\hline \multicolumn{2}{|l|}{ Pre-modern } & \multirow{2}{*}{$\begin{array}{l}\text { Modern } \\
\text { Nationally co-ordinated }\end{array}$} & \multirow{2}{*}{$\begin{array}{l}\text { Post-modern } \\
\text { Nationally co-ordinated } \\
\text { but decentralised } \\
\text { operations }\end{array}$} \\
\hline Campaign organisation & Local and decentralized & & \\
\hline Preparations & $\begin{array}{l}\text { Short term and ad hoc } \\
\text { campaign }\end{array}$ & Long campaign & Permanent campaign \\
\hline Central co-ordination & Party leaders & $\begin{array}{l}\text { Central headquarters, } \\
\text { more specialist } \\
\text { consultants, and party } \\
\text { officials }\end{array}$ & $\begin{array}{l}\text { More outside } \\
\text { consultants, pollsters } \\
\text { and specialist } \\
\text { campaign departments }\end{array}$ \\
\hline Feedback & Local canvassing & Opinion polls & $\begin{array}{l}\text { Opinion polls, focus } \\
\text { groups, Internet web } \\
\text { sites }\end{array}$ \\
\hline Media & $\begin{array}{l}\text { National and local } \\
\text { press } \\
\text { Local handbills, posters } \\
\text { and pamphlets } \\
\text { Radio leadership } \\
\text { speeches }\end{array}$ & $\begin{array}{l}\text { Television broadcasting } \\
\text { through major territorial } \\
\text { channels }\end{array}$ & $\begin{array}{l}\text { Television narrow } \\
\text { casting through } \\
\text { fragmented channels, } \\
\text { selective mailshots, } \\
\text { selective } \\
\text { advertisements }\end{array}$ \\
\hline Campaign events & $\begin{array}{l}\text { Local public meetings } \\
\text { Limited whistle-stop } \\
\text { leadership tours }\end{array}$ & $\begin{array}{l}\text { Media management } \\
\text { Daily press } \\
\text { conferences } \\
\text { Themed photo } \\
\text { opportunities, } \\
\text { TV party political } \\
\text { broadcasts } \\
\text { Billboard wars }\end{array}$ & $\begin{array}{l}\text { Extension of media } \\
\text { management to } \\
\text { "routine" politics, } \\
\text { leadership speeches, } \\
\text { policy launches etc. }\end{array}$ \\
\hline Costs & $\begin{array}{l}\text { Low budget and local } \\
\text { costs }\end{array}$ & $\begin{array}{l}\text { Higher costs for } \\
\text { producing television } \\
\text { party political } \\
\text { broadcasts }\end{array}$ & $\begin{array}{l}\text { Higher costs for } \\
\text { consultants, research } \\
\text { and television } \\
\text { advertisements }\end{array}$ \\
\hline
\end{tabular}

Source: Norris (1997a: 77) 


\section{Post-Modern Campaigning}

Some researchers argue that, given the international exchange of campaign techniques and personnel, and increased complexity of society election campaigning has reached its post-modern stage (Negrine 1996, Norris 1997a, 1997b). Table 1. illustrates the main changes in campaign evolution.

Some researchers believe that that the process of Americanisation disconnects leaders and voters, over-simplifies and trivialises political discourse and produces a cynical and disengaged public (Franklin 1994).

\section{Conclusion and Reflection}

Political Marketing has emerged as a major area of research, which has begun to reflect the growing internationalism and professionalism of political campaigning. Research focused initially on image and use of the marketing mix and it's adoption. It is now beginning to become a more substantive area of market research and work has more recently focused on segmentation of voters, strategy, buyer/consumer behaviour and exchange processes in political lobbying. The subject had its origins in the US but more recently has become established in Europe, with leading theory and research being developed in the UK. .

\section{References:}

Agranoff, R. (Ed.). (1972). The new style in election campaigns. Boston: Holbrook Press.

Baines, P. Harris, P. and Lewis, B. (2002). The Political Marketing Planning Process: Improving Image, (forthcoming publication), Vol 20 Marketing Intelligence and Planning.

Bartels, L. (1987). Candidate choice and the dynamics of the presidential nominating process. American Journal of Politics, 31, pp. 1-30.

Beresford, Q. (1998). Selling democracy short: Elections in the age of the market. Current Affairs Bulletin, Vol. 74, No. 5, pp. 24-32.

Biocca, F. (Ed.). (1991). Television and political advertising: Volume 1, Psychological Processes. New York: Lawrence Erlbaum.

Blumler, J. (1990). Elections, the media and the modern publicity process. In M. Ferguson (Ed.), Public communication - The new imperatives: Future directions for media research pp. 101-113. London: Sage.

Blumler, J. Kavanagh, D. \& Nossiter, T. (1996). Modern communications versus traditional politics in Britain: Unstable marriage of convenience. In D. Swanson \& P. Mancini (Eds.) Politics, media and modern democracy. Wesport, CT: Praeger.

Butler, P. \& Collins, N. (1994). Political marketing: structure and process. European Journal of Marketing. 28 (1). pp. 19-32.

Butler, D. \& Kavanagh, D. (1992). The British general election of 1992. London: Macmillan.

Butler, D. \& Ranney, A. (1992). Electioneering: A comparative study of 
continuity and change. Oxford: Clarendon Press.

Carmines, E. And Stimson, J. (1980). The two faces of issues voting. American Political Science Review, 74, March, pp. 78-91.

Crewe, I. \& King, A. (1994). Did Major win? Did Kinnock lose? Leadership effects in the 1992 British general election. In A. Heath (Ed.). Labour's last chance? London: Dartmouth.

Crewe, I. \& Gosschalk, B. (1995). (Eds.). Political communications: The general election campaign of 1992. Cambridge: CUP.

Cutlip, S. (1994). The unseen power. Public relations: a history. New Jersey: Lawrence Erlbaum.

Cutlip, S., Center, A. \& Broom, G. (1985). Effective public relations. New Jersey: Prentice Hall.

Curran, J. \& Seaton, J. (1991). Power without responsibility: The press and broadcasting in Britain. London: Routledge.

Dean, D. \& Croft, R. (1997). Integrated or overrated: Political marketing on the net. Proceedings of the 31st Annual Conference of Academy of Marketing, Manchester Metropolitan University, volume 2, pp. 1275-1277.

Denver, D. \& Hands, G. (1992). Constituency campaigning. Parliamentary Affairs, 45, pp. 528-544.

De Vries, W. (1989). American campaign consulting: Trends and concerns. $P S$, March, pp. 21-25.

Downs, A. (1957). An economic theory of democracy. Harper \& Row.

Edelman, M. (1988). Constructing the political spectacle. Chicago: University of Chicago Press.

Egan, J. (1999). Political marketing: Lessons from the mainstream. Journal of Marketing Management. Vol. 15. No. 6. pp. 495-503.

Eldridge, J., Kitzinger, J., \& Williams, K. (1997). The mass media and power in modern Britain. Oxford: OUP.

Foley, M. (1993). The rise of the British presidency. Manchester: Manchester University Press.

Franklin, R. (1994). Packaging politics. London: Edward Arnold.

Garnham, N. (1986). The media and the public sphere. In P. Golding, G. Murdock and P. Schlesinger (Eds.) Communicating politics: Mass communication and the political process. Leicester: Leicester University Press.

Garnham, N. (1992). The media and the public sphere. In C. Calhoun (Ed.). Habermas and the public sphere pp. 359-376. Cambridge: MIT Press.

Giddens, A. (1990). The consequences of modernity. Cambridge: Polity Press.

Grant, W. (1987). Business and politics in Britain. London: Macmillan Education.

Grant, W. (1995). Pressure groups, politics and democracy in Britain. Hemel Hempstead: Harvester Wheatsheaf.

Grunig, J. E. (1992a). Excellence in public relations and communication management. Hillsdale, NJ: Lawrence Erlbaum.

Grunig, J. E. (1992b, January). On the effects of marketing, media relations, 
and public relations: Images, agendas, and relationships. Paper presented at the Second Professional Conference of the Herbert Quandt Communication Group. Berlin, Germany.

Grunig, L. (1993). Image and symbolic leadership: Using focus group research to brigde the gap. Journal of Public Relations Research, 5(2), pp. 95-125.

Habermas, J. (1978). Teoria e prassi della societa tecnologica [Theory and praxis in technological society]. Bari, Italy: Laterza.

Habermas, J. (1984). The theory of communicative action I: Reason and the rationalisation of society. Boston, MA: Beacon Press.

Haberman, D. \& Dolphin, H. (1988). Public relations: The necessary art. Ames: lowa State University Press.

Harris, P (2001). Machiavelli, Political Marketing and Reinventing Government, European Journal of Marketing, Vol 35, (9/10).

Harris, P. \& Lock, A. (1996). Political marketing: More questions than answers. Proceedings of the M.E.G. Conference, University of Strathclyde.

Harris, P. \& Lock, A. (1996a). Political marketing - vive la difference! European Journal of Marketing, Vol. 30, (10/11), pp. 21-31.

Harris, P. \& Lock, A. (1996b). Machiavellian marketing: the development of corporate lobbying in the UK. Journal of Marketing Management, 12, pp. 313-328.

Harris, P; Lock, A. and O'Shaughnessy, N. (1999). Measuring the effect of political advertising and the case of the 1995 Irish Divorce Referendum. Marketing Intelligence and Planning. 17, 6. pp. 272-279

Harris, P., Moss, D and Vetter, N. (1999), Machiavelli and Public Affairs: A Tale of Servants and their Princes, Journal of Communication Management, Vol 3, 3.

Harris, P., Gardner, H. \& Vetter, N. (1999). Goods over God. Lobbying nad political marketing: a case study of the campaign by the Shopping Hours Reform Council that changed Sunday Trading Laws in the UK. In B. Newman (Ed.). Handbook of political marketing. Thousand Oaks: Sage.

Harris, P. Lock, A. and Rees, P.L. (eds), (2000), Machievelli,, Marketing and Management London: Routledge

Harris, P., and Moss., D. (2001), In Search of Public Affairs: A Function in search of an identity, Journal of Public Affairs, Vol.1, 1, pp. 102-112.

Harris, P. and Wring, D. (2002) Political Marketing, London, ButterworthHeinemann

Harrop, M. (1990). Political Marketing. Parliamentary Affairs. 43. pp. 277-292.

Hart, R. (1987). The sound of leadership: Presidential communication in the modern age. Chicago: University of Chicago Press.

Hayes, B. \& McAllister, I. (1996). Marketing politics to voters: Late deciders in the 1992 British election. European Journal of Marketing. Vol. 30 (10). pp. 135-146.

Heath, A., Jowell, R. \& Curtice, J. (1985). How Britain votes. Pergamon 
Himmelweit, H., Humphreys, P. \& Jaeger, M. (1985). How voters decide. Open University Press.

Jamieson, K. (1992). Dirty politics, deception, distraction \& democracy. Oxford: OUP.

Jones, N. (1995). Soundbites and spin doctors. London: Cassell.

Jowett, G. \& O'Donnell, V. (1992). Propaganda and persuasion. (2nd ed.) Newbury Park: Sage.

Kaid, L. \& Holtz-Bacha, C. (1995). Political advertising in western democracies. Thousands Oaks: Sage.

Kavanagh, D. (1970). Constituency electioneering in Britain. London: Longman.

Kavanagh, D. (1995). Election campaigning: the new marketing of politics. Oxford: Blackwell.

Kelly, S. Jr.(1956). Professional public relations and political power. Baltimore: John Hopkins.

Kessel, J. (1980). Presidential campaign politics: coalition strategies and citizen response. Homewood, Illinois: Dorsey Press.

Kotler, P. (1975). Marketing for non-profit organisations. New Jersey: Prentice Hall.

Kotler, P. \& Andreason, A. (1991). Strategic marketing for non-profit organisations. (4th ed.). Englewood Cliffs: Prentice Hall.

Kraus, S. \& Davis, D. (1976). The effects of mass communication on political behaviour. Pennsylvania State University Press

Lock, A. \& Harris, P. (1996). Political marketing - vive la difference! European Journal of Marketing, 30 (10/11), pp. 21-31.

Maarek, P. (1995). Political marketing and communication. London: John Libbey \& Co.

Marken, G. (1990). Corporate image - We all have one, but few work to protect and project it. Public Relations Quarterly, 35(1), pp. 21-23.

McCombs, M. \& Shaw, D. (1972). The agenda setting function of mass media. Public Opinion Quarterly, 36, pp. 176-187.

Moore, L. (1960). The manager and the image. In L. Bristol, Jr. (Ed.) Developing the corporate image: A management guide to public relations. New York: Scribner's.

McNair, B. (1996). Performance in politics and the politics of performance. In L'Etang, J. \& Pieczka, M. (Eds.). Critical perspectives in public relations. London: Thompson International.

McQuail, D. (1977). Analysis of newspaper content. London: HMSO.

McQuail, D. (1994). Mass communication theory - an introduction. London: Sage.

Melder, K. (1992). Hail to the candidate. Presidential campaigns from banners to broadcasts. London: Smithsonian Institute Press.

Murdock, G. (1993). Communications and the constitution of modernity. Media, culture and society, 15, pp. 521-539.

Negrine, R. (1989). Politics and the mass media. London: Routledge. 
Negrine, R. (1996). The communication of politics. London: Sage.

Newman, B. (1994). The marketing of the president: Political marketing as campaign strategy. London: Sage.

Newman, B. (Ed) (1999). Handbook of Political Marketing, Thousand Oaks, Sage

Niffenegger, P. (1990). Strategies for success from the political marketers. Journal of Consumer Marketing, 30, pp. 45-51.

Nimmo, D. (1970). The political persuaders: The techniques of modern election campaigns. Englewood Cliffs, N. J. : Prentice Hall.

Nimmo, D. (1974). Images and voters' decision making process. Advances in Consumer Research, 1, pp. 771-781.

Norris, P. (1997a). Political communications. In Dunleavy, P., Gamble, A., Holliday, I. \& Peele, G. (Eds.). Developments in British politics. London: Macmillan.

Norris, P. (1997b). Electoral change since 1945. Oxford: Blackwell.

Owen, D. (1991). Media messages in American presidential elections. New York: Greenwood.

O'Shaughnessy, N. (1990). The phenomenon of political marketing. London: Macmillan.

O'Shaughnessy, N. (1996). Social propaganda and social marketing: a critical difference? European Journal of Marketing, 30, 10/11, pp. 62-75.

Panebianco, A. (1988). Political parties: organisation and power. Cambridge:CUP.

Peele, G. (1982). Campaign consultants. Electoral studies, 1(3), pp. 355-262.

Perry, J. (1968). The new politics. London: Weidenfeld \& Nicolson.

Pincus, J., Rayfield, R. \& DeBonis, J. (1991, November). Transforming CEOs into chief communications officers. Public Relations Journal, pp. 22-27.

Popkin, S. (1991). The reasoning voter: communication and persuasion in presidential campaigns. Chicago and London: University of Chicago Press.

Pritkanis, A. \& Aronson, E. (1992). Age of propaganda. San Francisco: W.H. Freeman.

Reid, D. (1988). Marketing the political product. European Journal of Marketing. Vol. 22 (9), pp. 34-47.

Richardson, J. (1993). Pressure groups. Oxford: OUP.

Rothschild, M. (1978). Political advertising: A neglected policy issue in marketing. Journal of Marketing Research, 15, pp. 59-71.

Sabato, L. (1981). The rise of political consultants - new ways of winning elections. New York: Basic Books.

Salmon, C. (1989). Campaigns for social improvement: an overview of values, rationales and impacts. Sage Annual Reviews of Communication Research, Vol. 18.

Saunders, M., Lewis, P., \& Thornhill, A. (1997). Research Methods for business students. London: Pitman.

Scammell, M. (1995 ). Designer politics: How elections are won. London: Macmillan. 
Scammell, M. (1996). The odd couple: Marketing and Maggie. European Journal of Marketing. 30. pp. 122-134.

Semetko, H., Blumler, J., Gurevitz, M., \& Weaver, D., with Barkin, S., \& Wilhoit, G. (1991). The formation of campaign agendas: A comparative analysis of party and media roles in recent American and British elections. Hillsdale, N.J.: Erlbaum.

Smith, M. J. (1993). Pressure, power and policy: State autonomy and policy networks in Britain and the United States. Hemel Hempstead: Harvester Wheatsheaf.

Smith, G. \& Saunders, J. (1990). The application of marketing to British politics. Journal of Marketing Management, Vol. 5 No. 3, pp. 295-306.

Swanson, D. (1993). Political institutions in media-centred democracy. Paper presented at the course on Parliament and Public Opinion sponsored by the Universidad Complutense de Madrid, El Escorial, Spain, 2-6 August.

Swanson, D. \& Manchini, P. (1996). Politics, media and modern democracy. Westport: Praeger.

Tomlinson, J. (1994). A phenomenology of globalisation? Giddens on global modernity. European Journal of Communication, 9, pp. 149-173.

Tunstall, J. (1977). The media are American. London: Constable.

Weaver, D. (1980). Audience need for orientation and media effects. Communication Research, 7, 3, pp. 361-376.

Worcester, R. (1987). The triangular equation behind the Tory victory. The Times. 13 June.

Worcester, R. (1991). British public opinion. Oxford: Blackwell.

Wring, D. (1996). Political marketing and party development in Britain. European Journal of Marketing. 30. pp. 100-111.

Wring. D. (1997). Reconciling marketing with political science. Journal of Marketing Management, Vol. 13, No. 7, pp. 651-663.

\section{About the Author}

Dr Phil Harris is Chairman of the Academy of Marketing and a Reader in Marketing and Public Affairs at the Business School, Manchester Metropolitan University. He is Co-Director of the Centre for Corporate and Public Affairs, a research unit looking at corporate responsibility, political marketing, and public affairs. He is joint editor of the Journal of Public Affairs and serves on the boards of a number of leading marketing journals in the UK and US. He is a former parliamentary candidate at both the Westminster and European levels in the UK. A past Vice chairman of one of the political parties and has been a political advisor in the last six general election campaigns. His prime research interests are in strategic communications, stakeholder management and public affairs. He is a board member of the American Marketing Association Global interest group, a member of the CIM Academic Senate and Council. He has strong interest in Italian Renaissance literature and coined the term Machiavellian Marketing. 